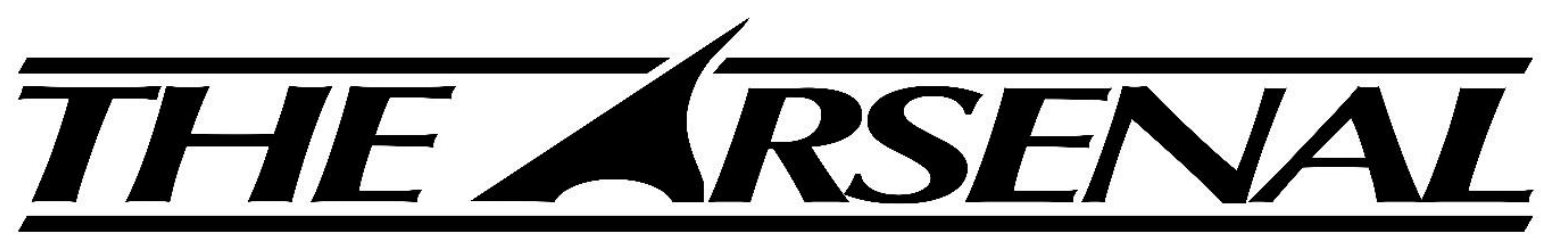

Augusta University's Undergraduate Research Journal

ISSN 2380-5064 | The Arsenal is published by the Augusta University Libraries | http://guides.augusta.edu/arsenal

Volume 4, Issue 1 (2021)

Special Edition Issue

\title{
INVESTIGATING THE EFFECTS OF ROSIGLITAZONE ON SHORT-TERM MEMORY THROUGH A PPAR-GAMMA DEPENDENT PATHWAY
}

Jayvon M. Nougaisse, Yun Lei, and Xinyun Lu

\section{Citation}

Nougaisse, J. M., Lei, Y., \& Lu, X. (2021). Investigating the effects of rosiglitazone on short-term memory through a ppar-gamma dependent pathway. The Arsenal: The Undergraduate Research Journal of Augusta University, 4(1), 28. http://doi.org/10.21633/issn.2380.5064/s.2021.04.01.28 


\section{Investigating the Effects of Rosiglitazone on Short-Term Memory through a PPAR-GAMMA Dependent Pathway}

Presenter(s): Jayvon M. Nougaisse

Author(s): Jayvon M. Nougaisse, Yun Lei, and Xinyun Lu

Faculty Sponsor(s): Yun Lei, DSC and Xinyun Lu, PhD

Affiliation(s): Department of Neuroscience and Regenerative Medicine (Augusta Univ.)

Funding: NIH

ABSTRACT

PPAR $\gamma$ agonists improve cognitive impairment in Alzheimer's Disease (AD) mouse models; however, little is known about the mechanisms by which they affect learning and memory. This study used PPAR $\gamma$-agonist Rosiglitazone to test the effects of PPAR $\gamma$ activation on short-term memory in young versus aged mice. Twenty-one-month-old (21 $\mathrm{MO})$ and 3-month-old (3 MO) male mice were separated into vehicle (n21MO=7, $\mathrm{n} 3 \mathrm{MO}=8)$ and treatment $(\mathrm{n}=8)$ groups. Y-Maze was conducted before and after injections. Mice were given three i.p. injections of saline or $10 \mathrm{mg} / \mathrm{kg}$ of rosiglitazone 24, 3, and 1 hour before testing. EthoVision XT was used to analyze the spontaneous alternation rate (SAR). Statistics are reported as Mean \pm SEM.

Results: Pre-injection SAR differences between groups were not significant for $3 \mathrm{MO}$ $(\mathrm{SARVeh}=60.35 \pm 3.27 \%$; SARRosig $=62.83 \pm 5.45 \% ; \mathrm{P}=.7021)$ and $21 \mathrm{MO}$

(SARVeh=58.40 $\pm 3.91 \%$, SARRosig $=61.99 \pm 3.89 \% ; \mathrm{P}=.5280$ ) mice. Post-injection SAR differences between groups were not significant for $3 \mathrm{MO}$ mice

(SARVeh=55.79 $\pm 3.28 \%$, SARRosig $=55.02 \pm 7.67 \% ; \mathrm{P}=.9278)$ but were significant for $21 \mathrm{MO}$ mice (SARPre $=61.35 \pm 5.03 \%$, SARPost $=38.83 \pm 6.58 \% ; \mathrm{P}=.0198$ ).

Conclusion: These results suggest that PPAR $\gamma$ activation had little effect in young mice but induced adverse effects in old mice, although i.p. injection-induced stress potentially affected results. Further research is needed to determine why rosiglitazone has contrary effects in $\mathrm{AD}$ and wildtype mice.

Received: 02/15/2021 Accepted: 03/30/2021

Correspondence: Jayvon M. Nougaisse, Augusta University, $112015^{\text {th }}$ St. Augusta, GA 30912, janougaisse@augusta.edu 